DOI 10.4467/25439561KSR.19.002.11304

\author{
BARBARA OCZKOWA
}

Uniwersytet Jagielloński

Kraków

\title{
ETNOGENEZA SŁOWIAN. HISTORIA BADAŃ
}

\author{
THE ETHNOGENESIS OF THE SLAVS. \\ HISTORY OF RESEARCH
}

\begin{abstract}
Streszczenie
Artykuł przedstawia, z konieczności szkicowo, historię badań nad etnogenezą Słowian. W czasach przednaukowych rozważania na ten temat znajdujemy już u starożytnych autorów, następnie zaś w średniowiecznych kronikach, aby stał się on wreszcie przedmiotem zainteresowań licznych uczonych, nie tylko językoznawców, którzy wysuwali rozmaite hipotezy dotyczące zarówno chronologii, jak i geograficznej lokalizacji praojczyzny Słowian. Problem „słowiańskiej kolebki” nie został jeszcze ostatecznie rozstrzygnięty, choć wśród licznych teorii dominują nadal dwie - autochtoniczna (zachodnia) i allochtoniczna (wschodnia). Problematyka etnogenezy Słowian jest obecnie także wykorzystywana politycznie. Świadczą o tym mity etnogenetyczne, które pojawiły się w kilku krajach słowiańskich.
\end{abstract}

\begin{abstract}
A given article presents briefly the history of research on the ethnogenesis of the Slavs. Some remarks upon the subject may be found already in the writings of the ancient authors and, later on, in the medieval chronicles. Finally, the issue in question caught attention of numerous academics, not only linguists. Various hypotheses concerning both the chronology and geographical locations of the homeland of the early Slavs have been suggested. These questions have not been yet definitely solved, though among the existing theories two may be regarded as predominant, namely co called the Western and Eastern one. Ethnogenesis of the
\end{abstract}

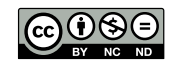


Slavs is now often used in politics; moreover, the ethnogenetical myths have recently gained a considerable popularity in some Slavic countries.

Słowa kluczowe: etnogeneza Słowian, praojczyzna, język prasłowiański, teoria autochtoniczna, teoria allochtoniczna, mity etnogenetyczne

Keyw ords: the Ethnogenesis of the Slavs, Slavic homeland, Proto-Slavic language, Eastern theory, Western theory, ethnogenetical myths

Etnogeneza Słowian to w slawistyce bez wątpienia najstarszy temat badawczy, jeden z najtrudniejszych, o ile nie najtrudniejszy i nadal jeszcze ostatecznie nierozstrzygnięty. Włączenie się w ostatnich latach do badań uczonych reprezentujących najnowsze dziedziny nauki, takie jak genetyka czy biochemia, budzi jednak nadzieję, że niektóre dotychczasowe hipotezy zamienią się w pewniki. To temat rzeka, toteż trudno było określić jego ramy, dokonać koniecznej selekcji zagadnień, podporządkowanej limitowi objętości artykułu. Z ogromu problematyki wybrałam przedstawienie długiej historii badań etnogenetycznych, a przede wszystkim towarzyszące im ,trudy naukowe”, w których rodziły się liczne teorie i hipotezy.

Pytanie o praojczyznę Słowian jest pytaniem „o czas i miejsce”, czyli z natury swej jest pytaniem historycznym, i dopiero poszukiwanie narzędzi przydatnych w znalezieniu na nie odpowiedzi angażuje naukowe warsztaty językoznawców, archeologów, antropologów, etnografów, a nawet etnomuzykologów, paleodemografów, paleobotaników, statystyków, a ostatnio zaś genetyków i biochemików.

Zatem zacznijmy od historii. Chociaż Słowianie notoryczni (nie domniemani) pojawiają się w źródłach historycznych dopiero w VI, VII w. n.e., to jednak wcześniej „u autorów starożytnych, greckich i rzymskich, spotkać można sporadyczne wzmianki świadczące o tym, że jakieś głuche wieści o Słowianach już do nich docierały". Tacyt (I w. n.e.) w Germanii wymienia Wenedów² jako wschodnich sąsiadów Germanów. W tym samym okresie Pliniusz Starszy w Historii naturalnej umieszcza Wenedów nad Oceanem Północnym, czyli Bałtykiem. Z kolei geograf aleksandryjski Ptolemeusz (II w. n.e.) w swoim Wstępie do geografii łączy lokalizację „ogromnego ludu” Wenedów z Zatoką i Górami Wenedzkimi. I tu pojawia się problem odczytywania antycznych źródeł historycznych. Dotyczy on zarówno lokalizacji, etnicznej interpretacji nazw, jak i etymologii etnonimów, które miały

1 W. Mańczak, Praojczyzna Słowian, Wrocław-Warszawa-Kraków-Gdańsk-Łódź, Ossolineum, 1981, s. 15. Autor wyczerpująco omawia źródła antyczne (ss. 15-27).

2 Za pierwotną postać uważa się nazwę Wenetów, zaś wariant $\mathrm{z}-d$ - za rezultat pośrednictwa germańskiego, za: H. Popowska-Taborska, Wczesne dzieje Słowian w świetle ich języka, Wrocław-Warszawa-Kraków, Ossolineum, 1991, s. 53. 
odnosić się do Słowian. Na przykład Zatokę i Góry Wenedzkie, na temat których trwała burzliwa dyskusja, uczeni utożsamiali z Zatoką Gdańską, Ryską lub Morzem Bałtyckim w ogóle, zaś Góry widziano na jakimś pogórzu pomorskim, w Górach Świętokrzyskich, Sudetach czy Karpatach. Nie tylko Wenetowie byli domniemanymi Słowianami. Już u greckiego historyka Herodota w V. w. p.n.e. w jego Dziejach pojawili się Scytowie-oracze zaliczani do Słowian oraz Neurowie i Budynowie ludy żyjące na obszarze dzisiejszego Podola i Wołynia, które część badaczy określa obecnie jako peryferyczne plemiona bałtyckie.

Dopiero od VI w. n.e. dysponujemy danymi o Słowianach notorycznych. Historyk łaciński Jordanes w Historii Gotów napisał, że ludy słowiańskie występują pod trzema nazwami: Wenedów, Antów i Sklawinów. Wenedowie zajmowali południowe wybrzeża Bałtyku i ziemie nad dolną Wisłą, Antowie ziemie między Dnieprem a Dniestrem, zaś Sklawinowie siedzieli między Cisą, Dniestrem a Dunajem. Prokopios z Cezarei, pisarz i historyk bizantyjski, w dziele $O$ wojnach wzbogaca ówczesną wiedzę o cenne informacje o ustroju, obyczajach i wierzeniach Antów i Sklawinów.

W starożytności, ale też i we wczesnym średniowieczu, powszechnie określano Słowian mianem Wenetów. Nazwa się spopularyzowała, stąd Lilla Weneda Słowackiego. Była to nazwa nadana im z zewnątrz, przez nich samych nieużywana, o wyraźnie obcym rodowodzie. Należy zatem do etnicznych nazw egzogenicznych, nadawanych przez sąsiadów w przeciwieństwie do nazw endogenicznych, pochodzących z języka danej grupy, która używa ich do samoidentyfikacji. W obu przypadkach działają one na zasadzie opozycji: swoi : obcy³. Stąd też nie dziwi fakt, że stała się przedmiotem licznych naukowych analiz, próbowano bowiem wykorzystać jej etymologię do lokalizacji praojczyzny Słowian. A etymologie były przeróżne. Przede wszystkim próbowano ją łączyć z terytorium słowiańskim. Zauważono rdzeń *ven- ze znaczeniem 'wilgoć, mokrość', ewentualnie *vętj- (pol. 'więcej') oraz słowiańskim słowotwórczym sufiksem -et-. Liczni oponenci podkreślają, że nazwa jest związana jednak z ludnością indoeuropejską z terenów nad Adriatykiem i Atlantykiem, konkretnie z językami italo-celtyckimi, w których ten rdzeń oznacza 'kochać', stąd nazwa oznaczałaby 'ludzi kochających ród'. Nie wiemy, jakim językiem mówili Wenedowie w I i II w. n.e. U Jordanisa są już Słowianami. Prawdopodobnie nazwa ta została im nadana przez Germanów (porównajmy niem. Wenden na określenie Połabian i Łużyczan czy Winden - Słoweńców) ${ }^{4}$. Można więc przypuszczać, „że Germanowie musieli wejść w kontakt z Wenetami jeszcze przed przybyciem Słowian na

3 Z. Gołąb, Nazwa etniczna Serbowie (sch. Srbi, głuż. Serbja || Serbi) na tle etnonimii stowiańskiej, [w:] Zbornik radova povodom 70. godišnjice života Jovana Vukovića, Sarajevo 1977, ss. 109-119, za: H. Popowska-Taborska, op. cit., s. 57.

4 Ciekawa jest także germańska pożyczka u Finów, którzy Rosję określają mianem Venäjä. Dla Maxa Vasmera był to dowód, że Weneci byli plemionami bałtyckimi. 
tereny nadbałtyckie"5. Byłby to zatem typ nazwy przejętej, podobnie jak słowiańscy Bułgarzy dziedziczą nazwę po tureckojęzycznych Protobułgarach.

Toteż, jak stwierdza Hanna Popowska-Taborska „wszelkie próby związane z utożsamianiem różnych ludów wymienianych w źródłach wcześniejszych z domniemanymi Słowianami pozostają jedynie w sferze lepiej lub gorzej podbudowanych faktami domysłów". W żadnym stopniu nie wskazują one pierwszych słowiańskich siedzib. Wartość danych historycznych jako zbyt późnych dla badań etnogenetycznych zakwestionował także Tadeusz Lehr-Spławiński w swojej pracy $O$ pochodzeniu i praojczyźnie Stowian (1946), o której w dalszej części artykułu.

Powracając jednak do tematu etnonimów. Opisani przez Jordanisa i Prokopiosa Sklawinowie to zgrecyzowana postać etnonimu Slověni, którym najprawdopodobniej Antowie określali sąsiadów - w znaczeniu 'pobratymców w języku'. I tu trzeba zająć się etymologią nazwy Stowianie. Rezultaty bardzo długich badań, pomijając rozważania przednaukowe, sprowadzają się do kilku głównych poglądów i wielu - nazwijmy je - oryginalnych. Licznych zwolenników miała etymologia łącząca etnomin z rdzeniem slov- : slav- 'ciec, płynąć', obecnym w nazwach wodnych, zgodnie z którą Słowianie byliby 'mieszkańcami terenów wilgotnych i bagnistych'. Przeciwnicy podkreślali, ,że nazwa tak znacznego etnosu nie mogła być określana za pomocą małego i niezidentyfikowanego obiektu topograficznego" . Propozycja Kazimierza Moszyńskiego oparta o modyfikację znaczenia rdzenia do 'czyścić' potwierdzonego w słowiańskich appellatiwach, np. 'nowina w lesie oczyszczona z zarośli i drzew', 'czyste pole, łąka' - sprowadzała Słowian do 'mieszkańców czystych pól'. Obie etymologie były jednak bezużyteczne dla wnioskowania o geograficznej lokalizacji praojczyzny. Liczni badacze skłaniają się do jednej ze starszych (Dobrovský, Šafařík) i przekonujących etymologii odwołujących się do slovo, ale przede wszystkim do czasownika sluti, slova, 'nazywać'. Etnonim Stowianie, czyli 'ludzie mówiący zrozumiale', określałby zatem grupę etniczną połączoną wspólnotą językową, innymi słowy językowych pobratymców. Jest to więc nazwa egzogeniczna o apelatywnej genezie (slovo). H. Popowska-Taborska stwierdza, że:

„Z przyjętego tu (i najmocniej chyba umotywowanego) założenia, że u podstaw nazwy Słowian leżał aspekt określania grupy za pomocą językowej wspólnoty, wnioskować należy o długo utrzymującej się bliskości językowej wszystkich Słowian i o łatwości ich wzajemnego porozumiewania się"s.

Ale także i ta etymologia nie zawiera wiedzy o miejscu pochodzenia.

\footnotetext{
H. Popowska-Taborska, op. cit., s. 55.

Ibidem, s. 30.

Ibidem, s. 58.

Ibidem, s. 62.
} 
Już jako ciekawostkę i na dowód tego, jak trudna jest sztuka etymologii wymieńmy kilka nietrafnych hipotez. Otóż wywodzono Słowian od rdzenia oznaczającego 'rolnika, tubylca' lub od gockiego slavan 'milczeć', ewentualnie od zaimka zwrotnego *slov, zgodnie z którym oznaczaliby 'swoich ludzi'. Z kolei Jan Baudouin de Courtenay (1915) wysunął hipotezę, że kupcy słowiańskich niewolników nazywali ich tak od powszechnego wśród nich imienia Staw-, co dało łac. Sclavus, Sclava. Pojawił się też mityczny Sław, występujący w kronikach, czyli Słowianie to byłby 'lud Sława'.

Powracając do nowszych źródeł, które miały dostarczać wiedzy tak o pochodzeniu Słowian, jak i ich praojczyźnie, trzeba wymienić Anonima Raweńskiego (lub Kosmografa z Rawenny), czyli geografa, astronoma, geologa i meteorologa z przełomu VII i VIII w., który opisuje świat jako koło otoczone oceanem nienadającym się do żeglugi.

„Położenie poszczególnych krajów i ludów określa Anonim R. wg podziału doby na 24 godz; 12 godzin dziennych oznacza ziemie płd., godziny nocne - ziemie płn. Około godz. 6 w nocy tj. w stronie płn.-wsch., wg Anonima R., «jest ojczyzna Scytów, skąd wywodzą się plem. Słowian»"10.

Skrócony z konieczności przegląd kronik stricte słowiańskich zacznijmy od najstarszej Powieści minionych lat Nestora (XII w.) Kroniki rozpoczynały się od początku legendarnego świata, tak więc także u Nestora ludy słowiańskie pojawiają się po zburzeniu wieży Babel i rozdzieleniu się narodów oraz języków. Słowianie u niego wywodzą się od Jafeta, jednego z synów Noego:

„Po mnogich zaś latach siedli byli Słowianie nad Dunajem, gdzie teraz ziemia węgierska i bułgarska. I od tych Słowian rozeszli się po ziemi i przezwali się imionami od miejsc, na których siedli”"11.

W różnych kronikach występują różne wersje biblijnej genealogii domniemanego ojca Słowian. Powtarza się także Panonia. I tak u Jana Długosza (1480) czytamy:

„Tedy potomek synów Jafeta, prarodzic wszystkich Słowian, wyszedłszy ze stepu Sennar [...] przekroczył rzekę Hister, którą teraz nazywamy Dunaj [...] z synami, powinowatymi i krewnymi swymi osiadł najpierw w Panonii, najpierwszej i najstarszej Słowian siedzi-

9 Ibidem, ss. 59-60.

${ }_{10}$ Słownik starożytności stowiańskich. Encyklopedyczny zarys kultury Stowian od czasów najdawniejszych, t. I, red. W. Kowalenko, G. Labuda, T. Lehr-Spławiński, Wrocław, Wiedza Powszechna, 1961, s. 34.

${ }^{11}$ Powieść minionych lat, tłum. i oprac. F. Sielicki, Wrocław-Warszawa-Kraków, Biblioteka Narodowa, nr 244, Ser. II, Ossolineum, 1999, s. 5. 
bie, kolebce ich i żywicielce, która obecnie [...] przezwisko Hungarii uzyskała. [...] Dwaj przeto synowie [...] potomka Jafeta, Lech i Czech, którym podlegały Dalmacja syrmska, Slawonia, Chorwacja i Bośnia [...], porzuciwszy pierwotną ojczyznę zdecydowali się wyszukać nowe siedziby i zaludnić je"12.

We wcześniejszej Kronice wielkopolskiej z XIII w. kolebką jest także Panonia, a jej mieszkańcy ,wywodzą się [...] od Janusa, potomka Jafeta. Z tych więc Panończyków pochodzili trzej bracia [...], z których pierworodny miał na imię Lech, drugi Rus, trzeci Czech. I ci trzej wydawszy potomstwo z siebie i ze swego rodu, posiadali trzy królestwa: Lechitów, Rusinów i Czechów"13.

Kronikarze nie byli zgodni co do osoby praojca, ponieważ obok Janusa w Kronice Stryjkowskiego z 1582 roku pojawia się Mosoch, szósty syn Jafeta, zaś w Opisie Sarmacji Macieja Miechowity (XV/XVI) Jawan - czwarty syn. Wskazanie na słowiańską praojczyznę panońską jest aktualne zresztą do dziś (tam lokalizuje ją np. Kobyczew w 1973 roku, a także V. Trbuhović oraz Trubaczow).

Zwolennikiem teorii panońskiej był również chorwacki kanonik z Szybenika, wszechstronny uczony Faust Vrančić (XV/XVI), autor łacińskiej rozprawki $O$ Słowianach, czyli Sarmatach adresowanej do krakowskiego kanonika Krzysztofa Warszewickiego, współwyznawcy w poglądach, a będącej wykładnią myśli Vrančicia na temat praojczyzny, późniejszych wędrówek Słowian (skądinąd częstego tematu w kronikach), ich wzajemnych stosunków i języka, którym się posługiwali.

U Marcina Bielskiego w Kronice z 1564 roku pojawia się nowa lokalizacja Sarmacja. Pisze on:

„Naród polski [...] poszedł jest z słowiańskiego narodu Sauromacjej, która leży w Europie, trzeciej części świata, dzieli tę Sarmacją od wschodu słońca rzeka Thanais [...] a od zachodu Wisła, albo jako drudzy chcą Odera rzeka"14.

Kolejną hipotezę - o bałkańskiej prakolebce - przedstawił dominikanin z Hvaru Vinko Pribojević (XV/XVI) w oracji wygłoszonej w 1525 roku, a wydanej drukiem w 1532, pt. De origine succesibusque Slavorum. Dowodem wspólnego słowiańskiego rodowodu była dla niego legenda o Lechu, Czechu i Rusie, z którą niewątpliwie zapoznał się podczas trzyletnich studiów na Uniwersytecie Jagiellońskim w latach 20. XVI wieku. Będąc zwolennikiem bałkańskiej praojczyzny Słowian, przyjmował tę wersję legendy, która głosiła, że bracia wyruszyli z południa na północ, stając się protoplastami plemion słowiańskich. Sięgając w głąb etnogenezy, Pribojević twier-

${ }^{12}$ Cyt za: H. Popowska-Taborska, op. cit., s. 7.

13 Ibidem.

${ }^{14}$ Ibidem. 
dził, że Słowianie pochodzą od starych Ilirów - stąd bałkańska lokalizacja kolebki Słowian. Według niego Ilir był jednym z dwunastu następców króla Tirasa, siódmego syna Jafeta, który, jak już wspomniano, był synem samego Noego.

Poruszamy się w świecie baśni i legend, ale one, choć nie wnoszą wartości naukowych, poświadczają tęsknotę Słowian do poznania własnych korzeni i określenia swojej tożsamości. Ale, co ciekawe, wątpliwości wobec takich prapoczątków wywodzących się „, Kroacyjej” wyraził wówczas Jan Kochanowski w pracy $O$ Czechu i Lechu historyja naganiona (post mortem, 1589).

I już zupełnie na marginesie wspomnę, że kroniki snuły też etymologie etnonimów nazw plemiennych, zarówno Słowian, jak i ich sąsiadów, które dla ówczesnych historiografów były jednym $\mathrm{z}$ materiałów dowodowych $\mathrm{w}$ poszukiwaniach kolebki. Pomijam to zagadnienie, ale wyjątek zrobię dla Wandali, plemienia wschodniogermańskiego przybyłego ze Skandynawii, a zajmującego od I do III w. n.e. tereny od środkowej i górnej Odry do Dunaju. Chcąc wyjaśnić ich nazwę, Wincenty Kadłubek (XII/XIII) w Historia polonica napisał: „od niej [Wandy] ma pochodzić rzeka Wandal, ponieważ ona stanowiła ośrodek jej królestwa, skąd wszyscy, którzy podlegali jej władzy, nazwani zostali Wandalami”"15. Jak thumaczył Henryk Łowmiański, Kadłubek od nazwy Wandalów utworzył imię-eponim: Wanda, a dalsi kronikarze wzbogacali jej życiorys o kolejne legendarne fakty - np. Kronika wielkopolska (XIII) donosi o jej samobójstwie w nurtach Wisły.

W czasach nowożytnych temat etnogenezy był nadal aktualny. I tak Adam Naruszewicz w Historii narodu polskiego od początku chrześcijaństwa $(1780,1824)$ okaże się wyznawcą teorii sarmackiej. Adam Mickiewicz odwołuje się do utrwalonych poglądów, pisząc w niepublikowanym za życia dziele Pierwsze wieki historii polskiej. Ks. I. Słowiańszczyzna od wyjścia jej z Azji do czasów Lecha, Czecha i Rusa, czyli Ruryka: „Z głębi Azji przed czasami Abrahama wyszło z pokolenia Jafeta plemię, które później nazwało się Słowianami"16. Ale w wykładach z literatury słowiańskiej (1843) zmienił zdanie: „Wiecie już Panowie, że ród słowiański od niepamiętnych czasów przebywał w Europie; Szafarzyk w swym encyklopedycznym dziele wyświetlił tę prawdę ponad wszelką wątpliwość" ${ }^{17}$. Chodzi tu o Stowiańskie starożytności (1836-1837). Są to już czasy początków filologii słowiańskiej. Jej ojciec Josef Dobrovský (1763-1829) w 1818 roku, uściślając niejako teorię bałkańską, wysunął hipotezę o pochodzeniu wszystkich Słowian od Serbów ${ }^{18}$. Jego pogląd

${ }^{15}$ Cyt. za: H. Popowska-Taborska, op. cit., s. 17.

16 A. Mickiewicz, Pierwsze wieki historii polskiej. Stowiańszczyzna od wyjścia jej z Azji do czasów Lecha, Czecha i Rusa, czyli Ruryka, Dzieła VII, Warszawa 1952, s. 7.

17 A. Mickiewicz, Literatura słowiańska, Literatura słowiańska, kurs III, wykład VI, Dzieła XI, Warszawa 1953, s. 202.

18 J. Dobrovský, Geschichte der böhemischen Sprache und ältern Literatur, Ganz umgearbeitete Ausgabe, Prag 1818. 
przejął Pavol Jozef Šafařík. Należałoby więc mówić o Praserbach zamiast o Prasłowianach. J. Dobrovský powoływał się na nazwę Spori, zanotowaną u Prokopiusa, którą uważał za zepsutą formę etnonimu Serbi. Obaj badacze porzucili później autochtonizm bałkański. Możemy przyjąć, że wczesny okres badań nad etnogenezą zamyka się w połowie XIX wieku, kiedy to wstępują one w nową fazę.

Badania te są klasycznym przykładem badań kompleksowych, interdyscyplinarnych, z podkreśleniem wartości i wagi analiz językoznawczych, archeologicznych i etnograficznych - w tej kolejności. Tradycja tego typu badań datuje się już od rozprawy Wawrzyńca Surowieckiego Śledzenie początku narodów stowiańskich wygłoszonej w 1824 roku. Praojczyznę lokował on w Azji Mniejszej wraz z Wenetami, których uważał za Słowian, choć nie zawsze. Odwoływał się do badań antropologicznych, konkretnie do zmienności cech pigmentacyjnych.

Klasycznym przykładem pracy interdyscyplinarnej jest wspomniana już monografia Tadeusza Lehra-Spławińskiego O pochodzeniu i praojczyźnie Stowian (1946), której argumenty bazowały na pracy antropologa Jana Czekanowskiego (Wstęp do historii Stowian. Perspektywy antropologiczne, etnograficzne, archeologiczne i jezykowe) z 1927 roku, a także tezach archeologów Józefa Kostrzewskiego i Konrada Jażdżewskiego. Praca jest dziś zdezaktualizowana. Autor twierdził, że na osiadłą pomiędzy Odrą a Wisłą ludność ugrofińską nawarstwili się idący z Turyngii (uważanej wówczas za praojczyznę Indoeuropejczyków) osadnicy, z których powstał etniczno-językowy zespół bałto-słowiański. Druga migracja indoeuropejska, tzw. Wenetów, zajęła część terytorium bałto-słowiańskiego, gdzie ostatecznie w wyniku długotrwałego rozwoju narodzili się Prasłowianie, różniący się od archaicznych Bałtów zasiedlających północ tego obszaru.

„Cechą charakterystyczną tej pracy, napisanej przecież przez językoznawcę, jest fakt, że materiały językowe w zasadzie nie doprowadzają jej autora do żadnych rozstrzygających wniosków. Podstawowa hipoteza T. Lehra-Spławińskiego dotycząca etnogenezy Słowian opiera się tu na faktach pozajęzykowych, wywód językoznawczy zaś polega na udowodnieniu, że dane językowe nie przeciwstawiają się wnioskom archeologicznym i antropologicznym" $"$.

- żeby przytoczyć ocenę Hanny Popowskiej-Taborskiej. Inną opinię o publikacji T. Lehra-Spławińskiego wypowiada Franciszek Sławski:

„Dzieło T. Lehra-Spławińskiego oceniać trzeba z perspektywy lat wojennych. Oddaje ono wiernie stan ówczesnych badań. Wywarło ogromny wpływ na badania następnych

${ }_{19}$ H. Popowska-Taborska, op. cit., s. 22. 
dziesięcioleci. Przyczyniło się niewątpliwie do ożywienia i pogłębienia badań nad praojczyzną Słowian"20.

W badaniach nad etnogenezą można zauważyć fakt, że każda postawiona hipoteza czy postulowana propozycja metodologiczna spotyka się z kontrpropozycją badawczą. Wspomniane wcześniej stanowisko Lehra-Spławińskiego negujące wartość badań historycznych podważa archeolog Witold Hensel, który przeznaczając archeologii rolę jedynie pomocniczą, na pierwszym miejscu stawia właśnie źródła historyczne. Swoją pracę Skąd przyszyli Słowianie? (1984) oparł na źródłach antycznych. Podobne stanowisko zajmował archeolog Konrad Jażdżewski.

Większość badaczy preferuje warsztat interdyscyplinarny, mniej liczni badania ograniczone do jednej dyscypliny. Do pierwszej grupy należą językoznawcy Witold Mańczak i Zbigniew Gołąb. Z kolei Aleksander Gardawski czy Kazimierz Godłowski odwołują się wyłącznie do „swojej” archeologii. Historyk Łowmiański nie doceniając archeologii, na pierwszym miejscu stawia językoznawstwo i historię. Podobnie sądzi Gerard Labuda:

„[...] Ani etnologia, ani tym bardziej archeologia nie potrafią przy pomocy własnych narzędzi badawczych ustalić etnicznego rozmieszczenia poszczególnych kultur (lub: kręgów kulturowych), ani też stwierdzić ich chronologicznego następstwa. Etykiety etniczne tym kulturom rozdaje językoznawstwo i historia operująca świadectwami pisanymi" ${ }^{21}$.

Do opinii krytycznych przyczyniła się niewątpliwie stosowana w archeologii metoda osadniczo-archeologiczna. Zaproponował ją w 1911 r. Gustaf Kossina, ,zaciekły niemiecki szowinista" (określenie W. Hensla) z główną tezą głoszącą, że Kulturgebiete sind Volksgebiete, czyli, że archeologiczne obszary kulturowe pokrywają się z obszarami zajmowanymi przez grupy etniczne. Niestety, ,[...] mimo iż wskazywano na jej ukryte, nienaukowe źródło związane z szerzeniem mitu pragermańskiego"22 oraz nieprzydatność w badaniach etnogenetycznych, spory wokół jej błędnych założeń toczyły się przez pół wieku, skutecznie hamując zastosowanie nowych metod. Głównym kontrargumentem był fakt, że granice kulturowe mogą, ale nie muszą, się pokrywać. Jako przykład Z. Gołąb przytoczył Wileńszczyznę, gdzie językowa slawizacja nie wywołała zmiany kultury materialnej oraz odwrotną

${ }^{20}$ F. Sławski, „O pochodzeniu i praojczyźnie Stowian” Tadeusza Lehra-Spławińskiego po pięćdziesięciu latach, [w:] Prasłowiańszczyzna i jej rozpad, red. J. Rusek, W. Boryś, Warszawa, Wydawnictwo Energeia, 1998, s. 20.

${ }^{21}$ G. Labuda, Fragmenty dziejów Stowiańszczyzny zachodniej, t. III, Poznań 1975, s. 45, cyt. za: H. Popowska-Taborska, op. cit., s. 25.

${ }_{22}$ W. Hensel, Etnogeneza Stowian, [w:] Mały stownik kultury dawnych Stowian, red. L. Leciejewicz, Warszawa, Wiedza Powszechna, 1990, s. 433. 
sytuację bałkańskich Wołochów, którzy zmieniając kulturę z wędrownej pasterskiej na osiadłą rolniczą, zachowali język, nie ulegając slawizacji23.

W archeologii tradycyjnie wyróżniano dwa przeciwstawne poglądy nt. etnogenezy: autochtonistów i allochtonistów. Ci pierwsi lokalizowali praojczyznę na terenie Polski lub bardziej od niej na zachód. Twórcą tej koncepcji był J. Kostrzewski, którego poglądy ewoluowały od 1913 roku (do jego zwolenników należeli M. Rudnicki, K. Jażdżewski, J. Czekanowski, T. Lehr-Spławiński), tak jak i zmieniła się nazwa teorii na neoautochtoniczną, choć powinna raczej być określana jako środkowo-nadłabsko-nadwiślańska lub nadbużańska. Z kolei allochtoniści (Kazimierz Godłowski, Michał Parczewski) widzieli praojczyznę na większym obszarze w dorzeczu Dniepru i Prypeci, skąd Słowianie mieli wyruszyć w V i VI w. n.e. na tereny środkowej i południowej Europy. W dorzecza Odry i Wisły przybyli nie wcześniej niż w połowie V w. n.e. Mieli wówczas zająć obszary stuletniej „pustki osadniczej”, opuszczonej przez poprzednich mieszkańców, a nowo przybyli reprezentowali już inny typ kulturowy. Allochtoniści uważają, że niesłusznie ograniczano Prasłowian do przedstawicieli jedynie kultury łużyckiej lub do kultur wołyńskich względnie naddnieprzańskich, ponieważ należą oni do wszystkich tu wymienionych. Nowym elementem w dyskusji jest propozycja W. Hensla tzw. etnicznej szachownicy czy pasów mieszanych istniejących „między terytoriami słowiańskimi i plemion sąsiednich, zamieszkałych przez ludność mieszaną pod względem językowym" "24. Mówi ona o koegzystencji różnych etnosów w tych samych kręgach kulturowych. Nie można też zapominać o zjawisku nawarstwień etnicznych powstałych w wyniku ekspansji innych ludów: Scytów, Ilirów (pozostawili Śrem), zeslawizowanych Celtów czy Germanów. W. Hensel tak opisuje Prasłowiańszczyznę:

„Procesu rozwoju Prasłowiańszczyzny nie można sobie wyobrazić jako stałego wzrostu zasięgu terytorialnego. Były w jej dziejach okresy, w których przynależne do niej plemiona powiększały swe dzierżawy, ale następowały po nich lata, gdy pod naciskiem różnych ludów dość wydatnie kurczyły się jej granice. Na niektórych ziemiach dochodziło zapewne do pełnego wyniszczenia dawnej macierzystej ludności i nieraz dopiero później następowała ich reslawizacja. W dobie prasłow. granice między ludami nie przebiegały też podobnie jak dziś. Różne ludy współzamieszkiwały niekiedy na jednym terytorium, często następowały przemarsze obcych grup. Ponieważ ludność miejscowa przeważała na nich, można mówić o istnieniu obszarów etnicznie poniekąd jednorodnych. Na pograniczach występowały natomiast szerokie pasy o wybitnie mieszanych cechach" 25 .

${ }_{23}$ Z. Gołąb, Etnogenezata na Slovenite vo svetlinata na lingvistikata, „Makedonski Jazik” 1968, nr XIX, ss. 5-20, 1969, nr XX, ss. 105-125, za: H. Popowska-Taborska, op. cit.

${ }^{24}$ W. Hensel, op. cit., ss. 438-439.

${ }^{25}$ Ibidem, ss. 443-444. 
Wyniki badań antropologicznych - kolejnej dyscypliny - nie były doceniane. Sam Czekanowski ubolewał nad ograniczonym materiałem badawczym, np. kostnym, spowodowanym ciałopalnym obrządkiem grzebalnym u Słowian aż do czasów chrystianizacji. Udało mu się jednak stwierdzić ciągłość zaludnienia terenów pomiędzy Bałtykiem a Karpatami i Sudetami od neolitu po teraźniejszość. Antropolodzy (główni badacze podejmujący tematykę etnogenetyczną to Andrzej Wierciński i Janusz Piontek, a także Wojciech Kočka) opowiadali się za zachodnią (Odra-Wisła) praojczyzną. Odwoływali się do badań cech morfologicznych, ale ostatnio metody typologiczne z antropologii fizycznej zastąpiono nowymi z paleodemografii, podejmując tym samym dyskusję z twierdzeniami o wielkim przyroście naturalnym Słowian w V i VI w., który wywołał ich ekspansję na zachód, jak twierdzili archeolodzy (K. Godłowski, M. Parczewski). Dalsze prace wykazały jednak, że tereny w dorzeczach Prypeci, Prutu i Dniepru były zamieszkałe przez ludność o niskiej dynamice biologicznej i nikłym przyroście naturalnym. Badania te podważają więc lokalizację wschodnią. Antropolodzy wykorzystują także cechy odontologiczne, czyli badania uzębienia. Na podstawie tych analiz opowiadają się oni za zachodnią prakolebką.

W pracach interdyscyplinarnych bierze też udział etnografia. Jej wiodący uczony Kazimierz Moszyński, autor monumentalnej 3-tomowej Kultury ludowej Stowian (1929-1939), przypisywał jej dużą rolę. W pracy O sposobach badania kultury materialnej Prastowian (1962) stwierdzał,

„,iz przy stosowaniu metody geograficznej możliwe jest nie tylko przypisanie Prasłowianom określonych wytworów materialnej kultury, lecz również wykluczenie pewnych wytworów z prasłowiańskiego zasobu kulturowego. Równocześnie jednak badacz ten wielokrotnie przestrzegał przed pochopnym nadawaniem treści etnicznych wytworom kultury, gdyż za podstawowy wyróżnik etnicznej wspólnoty przyjmował on kryterium językowe" ${ }^{26}$.

Z kolei Krzysztof Wrocławski (1983) podkreślał wartość podań i opowieści ludowych o istotach i siłach nadprzyrodzonych, jak i legend przedchrześcijańskich, ponieważ ten materiał mógłby pozwolić na rekonstrukcję świata Słowian - jak go oni rozumieli i budowali ${ }^{27}$. Badania te znajdują się w fazie początkowej, podobnie jak i te nad etnomuzykologią słowiańską.

Do prac w ostatnich latach dołączyli także genetycy (którym został poświęcony osobny artykuł), jak i biolodzy oraz biochemicy. Te dziedziny stosują najnowocze-

${ }^{26}$ H. Popowska-Taborska, op. cit., s. 31.

${ }^{27}$ K. Wrocławski, Studia porównawcze nad ludowa proza stowiańska wobec badań nad etnogeneza Stowian, Z polskich studiów slawistycznych, Ser. 6, Literaturoznawstwo, folklorystyka, problematyka historyczna, Warszawa 1983, ss. 321-328. 
śniejsze techniki przydatne w chronologizacji artefaktów. W badaniach populacyjnych stosuje się metody izotopowego datowania materiałów, a izotopowa analiza szkliwa nazębnego wspomaga antropologów.

Nas, jako filologów, najbardziej interesują badania językoznawcze. Zacznijmy jednak od paleobotaniki, która ze względu na materiał badawczy zajmuje miejsce pogranicza językoznawstwa. Argumenty paleobotaniczne - badania zasięgów geograficznych nazw roślin i zwierząt uczeni przywołują od początku XX wieku (Hermann Hirt - 1905-1907; botanik Józef Rostafiński - 1908) - Kazimierz Moszyński w pracy Pierwotny zasięg języka prastowiańskiego z 1957 roku wykorzystuje do uzasadnienia swojej teorii praojczyzny, którą umieszczał na zachodnio-środkowym Podnieprzu. Twierdził, że nazwy drzew występujące na wschodzie (brzoza, dąb, wierzba, lipa, grab, sosna) były rodzime, zaś zachodnie (buk, jawor, modrzew, brzekinia, cis, jodła, trześnia) były obcego pochodzenia, czyli tym samym musiały być nieznane na terenie pierwotnych siedzib Słowian. Jego teza wywołała burzliwą dyskusję z udziałem wielu uczonych, np. W. Mańczaka, który pisał, ,że wszelkie spekulacje zmierzające do zlokalizowania praojczyzny Słowian na podstawie nazw roślin są w najwyższym stopniu zawodne"28. Ostatecznie kwestię tę rozstrzygnął w 2008 roku Zbigniew Babik w obszernej, wszechstronnie udokumentowanej monografii Pojednanie z lasem. W stulecie ,argumentu florystycznego” w slawistycznych badaniach etnogenetycznych (1908-2008), gdzie stwierdził:

„Natomiast tu i ówdzie utrzymujące się od półwiecza przekonanie, jakoby historia kilku (a tym bardziej wszystkich) drzew o dziś «niewschodnioeuropejskich» zasięgach wspierała allochtoniczną wizję pierwotnych siedzib i kierunków migracji Słowian, okazuje się całkowitym nieporozumieniem"29.

Badanie fitonimów jest tylko jednym z przykładów wpisujących się w szerszy kontekst badania zasięgów leksykalnych jako materiału przydatnego w lokalizacji praojczyzny. Należą tu także hydronimy, toponimy, wspomniane już etnonimy, słownictwo fizjograficzne itd. Uczeni wysuwają wiele zastrzeżeń co do wiarygodności źródeł leksykalnych w badaniach etnogenetycznych. System leksykalny nie jest materiałem tak pewnym i stabilnym jak system gramatyczny. Leksyka prasłowiańska była znacznie zróżnicowana. Każdy badany wyraz ma w zasadzie swoją historię i wymaga indywidualnej analizy z uwzględnieniem wszystkich towarzyszących mu czynników pozajęzykowych ${ }^{30}$.

${ }^{28}$ W. Mańczak, op. cit., s. 73.

${ }^{29}$ Z. Babik, Pojednanie z lasem. W stulecie ,argumentu florystycznego” w slawistycznych badaniach etnogenetycznych (1908-2008), Kraków 2008, s. XII. 2.

${ }^{30}$ H. Popowska-Taborska, op. cit., rozdz. VI, Rola leksyki w dociekaniach nad etnogeneza Słowian, ss. $92-120$. 
Jednakże jedna z teorii etnogenetycznych została oparta wyłącznie na dokumentacji leksykalnej. Jest to hipoteza W. Mańczaka z 1981 roku. Zastosowana przez niego metoda polegała na ustalaniu pokrewieństwa języków na podstawie zbadania frekwencji wyrazów podobnych występujących w wybranych tekstach. Pierwotnie porównywał biblię gocką z paralelnym tekstem litewskim, starocerkiewnym, średniobułgarskim i polskim. $Z$ porównania tekstów wysnuwał wnioski o bliższym lub dalszym sąsiedztwie badanych języków, a w konsekwencji o geograficznej lokalizacji badanych etnosów. Praojczyznę Słowian umieścił w dorzeczu Odry i Wisły, podobnie jak T. Lehr-Spławiński, choć obu różniły metody badawcze. Jego teoria uznana została za kontrowersyjną, wywołała dyskusję i szereg zarzutów ${ }^{31}$. Krytyka jego koncepcji wskazywała równocześnie na „wady” i ograniczenia leksyki w badaniach etnogenetycznych. Podkreślano, że porównywał on teksty z różnych epok, nie uwzględniał zapożyczeń, jak i pomijał wpływ historyczno-kulturowych uwarunkowań danej leksyki.

Powracając do konkretnej lokalizacji praojczyzny i zainteresowania tym tematem uczonych, sięgnijmy do listy W. Mańczaka, który w cennym wstępie do swojej monografii Praojczyzna Stowian wymienia 74 uczonych (różnych dyscyplin) oraz omawia ich poglądy na etnogenezę. Ten stan badań doprowadzony został do 1981 roku, a autor zastrzega, że nie jest on wyczerpujący. Konkludując, W. Mańczak stwierdził, że „praojczyzny Słowian szuka się na ogromnych obszarach sięgających od Łaby poza Ural i rozpościerających się od Dunaju po źródła Dniepru”32. W dodatku kilku uczonych zmieniało przekonania (rekordzista Henrik Birnbaum w 1975 roku w jednej książce zmienił je 4 razy, a marrysta Aleksandr Mongajt w 1949 roku twierdził, że praojczyzny nigdy nie było).

W tych indywidualnych stanowiskach (poza oryginalnymi hipotezami np. Ivana Popovicia (1958), że praojczyzna leżała gdzieś nad Bałtykiem, a według Stefana Mładenova - w Euroazji) można wyodrębnić kilka lokalizacji.

Historycznie należałoby zacząć od lokalizacji w środkowej Azji i roku 1925, którą wysunął K. Moszyński. Skrytykowany przez orientalistów, zweryfikował ją w 1957 roku, twierdząc, że przechodząc ze wschodu, Słowianie w I tysiącleciu p.n.e. znaleźli się nad Dnieprem. Jego pogląd zyskał wielu zwolenników. Należą do nich Aleksiej Szachmatow, Józef Rostafiński, Jan Rozwadowski, Max Vasmer, Gerard Labuda, Henryk Ułaszyn, wreszcie Franciszek Sławski, wskazujący na obszary zachodnio-środkowego Podnieprza. Była to lokalizacja allochtoniczna, obejmująca na wschód od Wisły tereny Wołynia (Bug-Słucz), Podola (środkowy Dniestr-Boh), Polesia (Bug-Prypeć-Dniepr-Desna), środkowego Dniepru aż do źródeł Donu. Na

\footnotetext{
${ }^{31}$ Np. H. Popowska-Taborska, op. cit., ss. 34-35, 94-96.

${ }^{32}$ W. Mańczak, op. cit., s. 12.
} 
Polesie jako na krainę pozbawioną gór, ale charakteryzującą się jarami i stromymi brzegami rzek, miały wskazywać badania Kazimierza Moszyńskiego i Nikity Tołstoja. Jednym z dowodów miał być appellatiw geograficzny brzeg w znaczeniu 'brzeg rzeki', podczas gdy jego indoeuropejski przodek oznaczał 'górę', podobnie jak w dzisiejszym języku niemieckim. Wnioskowano więc, że to przesunięcie semantyczne było rezultatem specyficznej fizjografii terenu w praojczyźnie, co miałoby wskazywać na Polesie.

Badanie etnogenezy Słowian ściśle wiąże się z zagadnieniem praojczyzny Indoeuropejczyków, wędrówkami i najstarszymi kontaktami Prasłowian z ludami indoeuropejskimi, wreszcie z chronologią języka prasłowiańskiego. Przykładem takich badań może być hipoteza Zbigniewa $\operatorname{Gołąba~}^{33}(1987,1992)$ - jak się uważa, najdojrzalsza synteza lat dziewięćdziesiątych. Lokuje on praojczyznę Indoeuropejczyków na stepach wschodnio-ukraińskich i południowo-rosyjskich. Ich część północną stanowili Pregermanie i Prebałtowie wraz z Presłowianami, zamieszkujący górne dorzecze Donu. Po migracji Pregermanów przodkowie Bałtów i Słowian przeżyli okres wspólnoty bałto-słowiańskiej ${ }^{34}$. Po roku 1000 p.n.e. Presłowianie przesunęli się w kierunku południowo-zachodnim, zrywając wspólnotę i stając się Prasłowianami. Na terenie dzisiejszego Podola i Wołynia zetknęli się z przodkami Italo-Celtów i stąd też pochodzą stare leksykalne związki słowiańsko-italo-celtyckie. Dalszą wędrówkę Słowian na zachód Gołąb wiąże z inwazją Scytów na tereny czarnomorskie (ok. 700 r. p.n.e.). Na przełomie obu er Prasłowianie zamieszkiwali lasostep ciągnący się od górnego Donu poprzez dorzecze środkowego Dniepru do dorzecza Wisły oraz górnej i środkowej Odry.

Korzenie wschodnie ma też hipoteza Henryka Łowmiańskiego zawarta w pierwszym tomie Początków Polski. Leszek Moszyński nazywa ją dynamiczną, ponieważ autor wędruje z Prasłowianami od praojczyzny Indoeuropejczyków znajdującej się nad dolną Wołgą i dalej na wschód, aż do Odry na zachodzie. Nad górnym Dnieprem nastąpił rozłam z Bałtami, którzy doszli do Bałtyku między Dźwiną i Niemnem. Prasłowianie zaś na tym ostatnim etapie wędrówki zajęli tereny między Bugiem i Odrą, slawizując zamieszkałą tu ludność staroeuropejską. Byli to Wenetowie, których nazwę Germanie przenieśli później na Słowian. H. Łowmiański godzi niejako tym samym teorię wschodnią z zachodnią, ponieważ część Prasłowian pozostała na

${ }_{33}$ Z. Gołąb, Etnogeneza Stowian w świetle językoznawstwa, [w:] Studia nad etnogeneza Stowian i kultura Europy wczesnośredniowiecznej, cz. I, Wrocław 1987, ss. 71-80; idem, The origins of the Slavs. A linguist's view, Columbus 1992.

${ }^{34}$ Datacje tej wspólnoty są różne, np. 2000-1000 lub 2000-1500 p.n.e. Niektórzy uczeni negują jej istnienie. Dowodem zaś są wspólne innowacje powstałe w jęz. prabałto-słowiańskim (np. rozszczepienie sonantów, powstanie złożonej odmiany przymiotnika, oparcie koniugacji na dwóch tematach fleksyjnych itd.). 
miejscu ich poprzedniego pobytu, czyli nad Prypecią i środkowym Dnieprem. Stąd też ,każde miejsce ich dłuższego pobytu może być w jakimś sensie uważane za ich praojczyznę, ale w istocie można za nią uważać tylko teren, na którym zatrzymali się na stałe" 35 .

Wyznawcami przeciwnej - zachodniej - teorii autochtonicznej byli wspomniani już T. Lehr-Spławiński, W. Mańczak, J. Nalepa oraz Tadeusz Milewski, chociaż ten ostatni

„paradoksalnie jednak dostarczył ważnych argumentów na rzecz lokalizacji wschodniej, wykrywając wpływy irańskie w imiennictwie słowiańskim [...] oraz nazwy pochodzenia wenetyjskiego i iliryjskiego na ziemiach polskich. Z drugiej strony odkryte przez T. Milewskiego późnoprasłowiańskie centrum innowacji w Panonii zostało wykorzystane przez O. Trubačova i L. Ossowskiego jako argument za umieszczeniem tam praojczyzny Słowian"36.

Przypomnijmy, że stosunkom prasłowiańsko-irańskim zawdzięczamy pojęcia z kultury duchowej: np. bogz, divz, nebo, slovo, pbati, piša.

Mająca wielu zwolenników teoria ,zachodnia” zyskała nowe objaśnienie, będące rezultatem badań V.V. Martynowa w latach 80. XX w. Sądzi on, że język protosłowiański, najogólniej mówiąc, powstał „w XII w. p.n.e. w zachodniej części substratu protobałtyckiego pod wpływem oddziaływań substratu italskiego i wytworzenia kultury łużyckiej"37. Następnie w V. p.n.e. przekształcił się w prasłowiański pod wpływem substratu irańskiego i upadku kultury łużyckiej.

Wymieniony Oleg Trubaczow jest przedstawicielem trzeciej, różniącej się od poprzednich teorii, tzw. panońskiej. Uczony ,zakłada mieszany charakter zasiedlenia dawnej Europy, nietrwałość granic etnicznych i tym samym znaczną ,przenikalność” prasłowiańskiego obszaru językowego"38. Odwołuje się do prasłowiańsko-praitalskich związków językowych oraz do słowiańsko-italsko-germańskich. Ilirowie przebywali na południe od Bałtyku, a kontakty Prasłowian z Celtami zaowocowały elementami kentumowymi w języku. Uzasadniając taką lokalizację, stwierdza, że

„teoria dunajskiej praojczyzny Słowian «nigdy nie utraciła w pełni swego uroku» i za jej rehabilitacją odzywają się i dziś głosy etnografów. Historia wschodnich Słowian zaczęła się niewątpliwie na południu, o czym świadczy między innymi ludowa pamięć o Dunaju,

35 L. Moszyński, Wstęp do filologii stowiańskiej, Warszawa, PWN, 1984, s. 175.

${ }^{36}$ L. Bednarczuk, Rozpad języka prastowiańskiego w świetle badań Tadeusza Milewskiego i nowszych hipotez etnogenetycznych, [w:] Prasłowiańszczyzna i jej rozpad, red. J. Rusek, W. Boryś, Warszawa 1998 , s. 329.

${ }^{37}$ H. Popowska-Taborska, op. cit., s. 143.

${ }^{38}$ Ibidem. 
żywa do dziś jeszcze na obszarze wschodniosłowiańskim. Być może więc rejon środkowego Dniepru był w swoim czasie peryferią obecnego obszaru wschodniosłowiańskiego, który należy lokalizować bardziej na południe" ${ }^{39}$.

W konsekwencji tej tezy obszary Słowiańszczyzny zachodniej zostały zasiedlone z południa.

Trzy przedstawione przeciwstawne hipotezy reprezentują trzy główne poglądy na temat etnogenezy. Czego nadal nie wiemy? Nie znamy lokalizacji praojczyzny Indoeuropejczyków (najnowsza teoria to turecka Anatolia), nie wiemy jak przebiegało jej rozbicie na prajęzyki poszczególnych 11 rodzin; nie znamy przyczyn rozłamu Prabałtów i Prasłowian, jak i czasu oraz miejsca tego zdarzenia. Nie mamy też pewnej wiedzy na temat chronologii kontaktów językowych Prasłowian z Italami, Germanami, Celtami, a także z językami irańskimi. Problem naszej praojczyzny jest nadal otwarty.

Pozostało jeszcze zagadnienie chronologii języka prasłowiańskiego. W przeciwieństwie do krytykowanych badań leksyki w rozstrzyganiu tego problemu pomocne okazały się fakty z nowej chronologizacji wczesnych słowiańskich zjawisk fonetycznych i morfologicznych. Zostały one zapoczątkowane w latach 60 . XX wieku ${ }^{40}$ i na ich podstawie zakłada się ciągłość prasłowiańszczyzny jako systemu językowego trwającego od XV w. p.n.e. aż do X w. n.e., czyli przez ok. 2500 lat, $\mathrm{z}$ równoczesnym podziałem jej na dwa różne etapy, z których pierwszy, trwający do V w. n.e., czyli do początków wielkich migracji Słowian, charakteryzował się niezwykle jednolitym rozwojem prajęzyka. F. Sławski okres ten nazywał „monolitem językowym”. W drugim okresie (od V do X w. n.e.) terytorialnie już rozległą Słowiańszczyznę zaczyna cechować dialektyczne zróżnicowanie języka prasłowiańskiego, stanowiące podstawę do późniejszego wyodrębnienia się poszczególnych języków słowiańskich. Tu zastrzeżenie, że są także inne propozycje chronologii języka prasłowiańskiego. Pewnym jest jednak fakt, że w X w. wraz z zanikiem jerów słabych przestało działać prawo sylab otwartych i tym samym nastąpił kres systemu samego języka prasłowiańskiego.

Etnogeneza Słowian została także zmitologizowana i upolityczniona. Pierwsi dokonali tego Chorwaci. W drugiej połowie XIX wieku na terenie dawnej greckiej kolonii Tanais (dziś Azow koło Rostowa nad Donem) odkryto 2 płyty nagrobne z II lub III w. n.e. z napisami Horoathos lub Horovathos, które stały się podstawą tezy,

\footnotetext{
39 Ibidem, s. 144.

${ }^{40}$ Należą tu badania dotyczące np. I palatalizacji, rozwoju $\overline{\mathrm{u}}>\mathrm{y}$, monoftongizacji dyftongów, powstania jerów oraz o < ă. Szerzej o tym H. Popowska-Taborska, op. cit., w rozdz. V, Fonetyczne różnicowanie się Stowiańszczyzny, ss. 73-91.
} 
że etnonim Chorwat jest pochodzenia irańskiego, a więc i Chorwaci są pochodzenia irańskiego, a nie słowiańskiego. Tak narodziła się irańska etnogeneza Chorwatów. W poszukiwaniu potwierdzających ją dowodów uczestniczyło wielu uczonych. Irańską genezę miały potwierdzać: dualistyczny charakter dawnych Słowian (zoroastryzm a bogomiłowie w Bośni), tradycja oznaczania stron świata kolorami, głagolica kanciasta, irańskie analogie w architekturze i ornamentyce (starochorwacka plecionka), symbol szachownicy, wyrazy z języka huryckiego w starochorwackim i dialektach, zbieżności akcentuacji staroperskiej i kajkawskiej oraz czakawskiej itd. Teoria ta żywotna była na emigracji, zaś w czasach Jugosławii, po II wojnie światowej, znajdowała się na indeksie jako przejaw chorwackiego nacjonalizmu. Obecnie jest ona szeroko propagowana, nawet przez instytucje naukowe ${ }^{41}$. Nie jest natomiast akceptowana przez chorwackich lingwistów, którzy nie wykluczając irańskiego pochodzenia etnonimu Chorwat, opowiadają się jednak za słowiańskim rodowodem Chorwatów. Jest to typowa etnogenetyczna legenda naukowa ${ }^{42}$. Niesłowiańskie pochodzenie lokuje Chorwatów daleko od „prymitywnych Bałkanów”, a jej dodatkową zaletą jest fakt, że zaprzecza ona pokrewieństwu języka chorwackiego z językiem serbskim.

Nie tylko Chorwaci stworzyli mit etnogenetyczny ${ }^{43}$. Każdy z narodów byłej Jugosławii buduje własny przekaz. Serbowie, podobnie jak Chorwaci, wywodzą siebie z Azji, a w jednej z wersji głoszonych przez „Serbską Szkołę Autochtoniczną” prezentują Serbów jako pierwszy naród na ziemi, od którego wywodzą się wszystkie inne narody ${ }^{44}$. Z kolei Chorwaci, w zwierciadlanym, dotyczącym Serbów ,,anty-micie" lokują ich w Afryce, skąd mieli przybyć do Europy jako rzymscy niewolnicy. Albańczycy, także mieszkańcy Bałkanu, na swoją praojczyznę również wybrali Azję, z której wyemigrowali na Bałkany, do Azji Mniejszej i Italii. W konsekwencji stali się przodkami Etrusków, Hellenów i Macedończyków. Popularny jest także mit ilirski, wywodzący wszystkich Albańczyków od Ilirów. Ale na Ilirów jako swych przodków wskazują także Serbowie.

${ }^{41}$ Istnieje Towarzystwo Naukowe ds. Badania Etnogenezy Chorwatów, które odwołuje się do dowodów genetycznych i paleolingwistycznych. Genom słowiański EU-19 posiada 23-29\% Chorwatów, zaś genom EU-7, płd.-wsch.-azjatycki - 45 \% Chorwatów.

${ }^{42}$ Szerzej o tym zob. J. Molas, Teoria o irańskim pochodzeniu Chorwatów - rozwój, funkcje i geneza, [w:] Problemy tożsamości kulturowej w krajach słowiańskich (Jej formy i przemiany), t. 2, red. J. Goszczyńska, Warszawa, Wydział Polonistyki UW, 2003, ss. 7-33.

${ }^{43}$ Odwołuję się do swego artykułu: Mit i język. Jak/czy językoznawstwo może kształtować świadomość polityczna i społeczna, [w:] Kultury słowiańskie między postkomunizmem a postmodernizmem 1989-2004, red. M. Dąbrowska-Partyka, Kraków, WUJ, 2009, ss. 295-306.

${ }^{44}$ Pogląd ten zaprezentowała w swojej książce O. Luković-Pijanović, Srbi narod najstariji, t. 1-2, Beograd 1990. Szerzej o tym I. Čolović, „Być panem u siebie”. Mity o autochtoniczności na Batkanach, [w:] idem, Bałkany - terror kultury, thum. M. Petryńska, Wołowiec 2007, ss. 137-153. 
Słoweńcy wyprowadzają swój rodowód od antycznych Wenedów, odrębnego plemienia słowiańskiego żyjącego niegdyś na terenach Słowenii, Austrii i Czech, a tym samym nie mającego nic wspólnego z innymi bałkańskimi narodami słowiańskimi.

W micie etnogenetycznym można wydzielić typ autochtoniczny, w którym szczególnie podkreśla się odwieczną obecność swojego narodu na danym obszarze, udowadniając jego niezaprzeczalne prawo do tych terenów. Wykorzystywano to jako przydatny argument polityczny w czasie ostatniej wojny, ale także jako element kształtujący nacjonalistyczny model świadomości społecznej. Bałkańską (obok światowej) autochtoniczność propagują Serbowie, ale też i inne nacje. Bośniacko-hercegowińscy Muzułmanie twierdzą, że jako autochtoniczny naród bałkański legitymizują się rodowodem sprzed czterech tysięcy lat. Macedończycy także od zamierzchłych czasów zamieszkują swoje ziemie, a Czarnogórcy, podobnie jak Chorwaci, zaprzeczają swojemu słowiańskiemu pochodzeniu, odwołując się do dowodów antropologicznych i datując swoją bałkańską obecność od epoki żelaza, czyli od około dziesięciu wieków p.n.e. Bułgarzy natomiast przywołują swoich protobułgarskich, a więc niesłowiańskich, przodków, którzy „roztopili” się w słowiańskiej większości. W niektórych opracowaniach wątek protobułgarski ulega jednak rozbudowaniu, co dokonuje się kosztem słowiańskiego pochodzenia dzisiejszych Bułgarów.

Mity etnogenetyczne łączą się też z językiem, sięgają bowiem do dowodów lingwistycznych, najczęściej etymologicznych (chorwackie wyrazy huryckie). Najdalej idą w swych „odkryciach” Serbowie, którzy w każdym wyrazie zawierającym $s, r, b$ widzą jego serbskie pochodzenie.

Mity etnogenetyczne są wykorzystywane do budowania tożsamości narodowej i konsolidacji społeczeństwa w nowym państwie. Rodzą poczucie dumy obywateli ze starożytności własnej nacji i państwa, wyższej kultury i tradycji niż ta, którą reprezentują otaczający ich sąsiedzi.

\section{Literatura}

Babik Z., Pojednanie z lasem. W stulecie ,, argumentu florystycznego” w slawistycznych badaniach etnogenetycznych (1908-2008), Kraków 2008, ss. XIV.7.

Bednarczuk L., Rozpad języka prastowiańskiego w świetle badań Tadeusza Milewskiego i nowszych hipotez etnogenetycznych, [w:] Prasłowiańszczyzna i jej rozpad, red. J. Rusek, W. Boryś, Warszawa, Wydawnictwo Energeia, 1998, ss. 329-336. Gołąb Z., Etnogeneza Stowian w świetle językoznawstwa, [w:] Studia nad etnogeneza Stowian i kultura Europy wczesnośredniowiecznej, cz. I, Wrocław 1987, ss. $71-80$. 
Gołąb Z., The Origins of the Slavs. A Linguist's View, Columbus 1992.

Hensel W., Etnogeneza Stowian, [w:] Maty stownik kultury dawnych Stowian, red.

L. Leciejewicz, Warszawa, Wiedza Powszechna, 1990, ss. 433-444.

Mańczak W., Praojczyzna Stowian, Wrocław-Warszawa-Kraków-Gdańsk-Łódź, Ossolineum, 1981, 154 ss.

Moszyński L., Wstęp do filologii słowiańskiej, Warszawa, PWN, 1984, 344 ss.

Oczkowa B., Mit i język. Jak/czy językoznawstwo może kształtować świadomość polityczna i spoleczna, [w:] Kultury stowiańskie między postkomunizmem a postmodernizmem 1989-2004, red. M. Dąbrowska-Partyka, Kraków, WUJ, 2009, ss. 295-306.

Popowska-Taborska H., Wczesne dzieje Stowian w świetle ich języka, WrocławWarszawa-Kraków, Ossolineum, 1991, 174 ss.

Sławski F., „O pochodzeniu i praojczyźnie Słowian” Tadeusza Lehra-Spławińskiego po pięćdziesięciu latach, [w:] Prastowiańszczyzna i jej rozpad, red. J. Rusek, W. Boryś, Warszawa, Wydawnictwo Energeia, 1998, ss. 17-20.

\section{References}

Babik Z., Pojednanie z lasem. W stulecie ,, argumentu florystycznego" w slawistycznych badaniach etnogenetycznych (1908-2008) [Reconciliation with the Forest. 100 Year Anniversary of 'Botanical Argumentation' in Slavic Ethnogenetical Research], Kraków 2008, pp. XIV.7.

Bednarczuk L., Rozpad języka prastowiańskiego w świetle badań Tadeusza Milewskiego i nowszych hipotez etnogenetycznych [Dissemination of the Proto-Slavic Language as Seen in the Resarch by Tadeusz Milewski and in Modern Ethnogenetical Hypotheses], [in:] Prastowiańszczyzna i jej rozpad [Proto-Slavic Language and Its Dissemination], ed. J. Rusek, W. Boryś, Warszawa, Wydawnictwo Energeia, 1998, pp. 329-336.

Gołąb Z., Etnogeneza Stowian w świetle językoznawstwa [Ethnogenesis of the Slavs in the Linguistic Perspective], [in:] Studia nad etnogeneza Stowian i kultura Europy wczesnośredniowiecznej [Studies in the Ethnogenesis of the Slavs and the Culture of Early Medieval Europe], Vol. I, Wrocław 1987, pp. 71-80;

Gołąb Z., The Origins of the Slavs. A Linguist's View, Columbus 1992.

Hensel W., Etnogeneza Stowian [Ethnogenesis of the Slavs], [in:] Maty stownik kultury dawnych Stowian [Concise Dictionary of the Culture of Early Slavs], ed. L. Leciejewicz, Warszawa, Wiedza Powszechna, 1990, pp. 433-444.

Mańczak W., Praojczyzna Stowian [Proto-Homeland of the Slavs], WrocławWarszawa-Kraków-Gdańsk-Lódź, Ossolineum, 1981, 154 pp. 
Moszyński L., Wstęp do filologii słowiańskiej [Introduction to Slavic Philology], Warszawa, PWN, 1984, 344 pp.

Oczkowa B., Mit i język. Jak/czy językoznawstwo może kształtować świadomość polityczna i spoleczna [Myth and Language. The Role of Linguistisc in Shaping the Political and Social Identity], [in:] Kultury stowiańskie między postkomunizmem a postmodernizmem 1989-2004 [Slavic Cultures Between Post-Communism and Post-Modernism 1989-2004], ed. M. Dąbrowska-Partyka, Kraków, WUJ, 2009, pp. 295-306.

Popowska-Taborska H., Wczesne dzieje Stowian w świetle ich języka [Early History of the Slavs in the Context of Their Language], Wrocław-Warszawa-Kraków, Ossolineum, 1991, 174 pp.

Sławski F., ,, O pochodzeniu i praojczyźnie Stowian” Tadeusza Lehra-Spławińskiego po pięćdziesięciu latach [On Tadeusz Lehr-Spławiński's Views on Origin and Proto-Homeland of the Slavs - After 50 Years], [in:] Prastowiańszczyzna i jej rozpad [Proto-Slavic Language and Its Dissemination], ed. J. Rusek, W. Boryś, Warszawa, Wydawnictwo Energeia, 1998, pp. 17-20. 